\title{
“EFFECTIVITY” IN INTERNATIONAL LAW: SELF-EMPOWERMENT AGAINST EPISTEMOLOGICAL CLAUSTROPHOBIA
}

\author{
Jean d'Aspremont*
}

Editor's note: The following is the third contribution to an AJIL Unbound symposium ${ }^{1}$ on "The Idea of Effective International Law," a continuation of the panel discussion ${ }^{2}$ at the 2014 ASIL-ILA joint meeting in Washington, DC.

$* * * *$

When we think of "effectivity," we usually come to think of a pragmatic and factual construction. The idea of effectivity, however, is anything but concrete and raises a variety of questions of legal theory, legal philosophy, epistemology, and theory of knowledge. It should also be highlighted that from a linguistic standpoint the word effectivity does not exist in British English. The attachment of the International Court of Justice to her Majesty's English explains that the World Court uses the French word (effectivité) when it seeks to refer to effectivity. These linguistic debates, however, matter less than the semantics and especially less than the consensus that effectivity ought to be opposed to "effectiveness."

Effectiveness refers to the outward impact of (primary and secondary) rules, institutions, and narratives of international law on international actors and lawappliers. In this sense, one way to see effectiveness is to equate it with the general state of a rule, institution, or narrative in terms of compliance. Effectivity, for its part, evokes an inward process whereby facts are integrated in rules, institutions, and narratives as a condition of the operation of law and thus a condition of valid legal reasoning. By virtue of the idea of effectivity, valid legal reasoning is made contingent on the empirical verification of a certain factual variable. Said differently, effectivity refers to the internalization of certain factual variables in the law itself, as a result of which valid legal reasoning is conditioned on the demonstration of certain facts.

The types of factual quality that are made a constitutive part of the operation of rule include (but are not limited to) the finding of an effective government, a certain behavioral practice for the sake of customary law, effective control for the sake of the extraterritorial application of human rights, effective control for the sake of attributing a behavior to a personified actor, the effective exercise of authority for the sake of belligerent occupation, and so on. Valid legal reasoning on the basis of these effectivity-based doctrines is thus made contingent on the realization of the factual variables concerned.

It is with such a distinction between effectivity and effectiveness in mind that three brief, rather elementary, observations on the idea of effectivity must now be formulated.

* Professor of Public International Law at the University of Manchester, Professor of International Legal Theory at the University of Amsterdam, and Director of the Manchester International Law Centre.

Originally published online 20 June 2014.

1 Vijay Padmanabhan, The Idea of Effective International Law: Continuing the Discussion, 108 AJIL UnBound 91 (2014).

${ }^{2}$ Gary J. Shaw, The Idea of Effective International Law, ASIL CABLES (Apr. 11, 2014).

ASIL and Jean d'Aspremont (C) 2014 


\section{The World of International Law and the Outside Universe}

The first contention I venture here is that the idea of effectivity operates as a bridge between the world of international law and what I would call an "outside universe." This is premised on the belief that international law creates a world of ideas (some people say "vocabularies"). The main ideas of the world of international law are States, International Organizations, Treaties, Customs, Wrongfulness, Territory, Crimes, etc. Strictly speaking, these ideas do not describe anything. They are ideas.

Unsurprisingly, most international lawyers are unhappy with the world of international law being solely a world of ideas. International lawyers want these ideas to reach out to an outside universe. This is the very reason why they have created another idea, meaning the idea of effectivity. Needless to say, effectivity is itself a mere idea among others. Yet the idea of effectivity allows the above-mentioned effectivity-based doctrines of international law to be connected with an outside universe. Said differently, the idea of effectivity is what allows these doctrines to operate outside the closed world of ideas. It allows these foundational doctrines to pierce and beam beyond the atmosphere of the world of international law and relate to the outside universe. It is in this sense that effectivity, as I understand it here, creates a bridge between the world of international law and an outside universe.

At this stage, it is essential to highlight that the bridge between the world of international law and the universe is bi-directional. Whilst effectivity creates a bridge between international law and the outside universe by making valid legal reasoning dependent on factual variables, it does not follow that the world of international law is automatically and unilaterally shaped after such an imported outside universe. Although global actors constantly shape international law in a way that allows the pursuit of certain agendas they see as in their selfinterest, it is important to realize that the universe imported into the world of international law by virtue of effectivity is, to a significant extent, constructed along the lines of the ideas (and descriptive categories) of the very same world of international law. In other words, this outside universe (made of effective government, effective control, behavioral practice, etc.), despite heavily bearing on the design of international law, is itself partly molded after the categories of the world of international law. At any time, this imported outside universe is a projection of the world of ideas of international law. The importation of the outside world as a result of effectivity is thus one facet of what constitutes an intricate dialectic process, for any import in the world of international law and its main doctrines by virtue of effectivity is equally shaped by a projection of the latter. The world that is imported into international law by virtue of effectivity is as much constitutive of international law as it is constituted by it.

\section{The Therapeutic Dimension of the Idea of Effectivity}

The contention made here that effectivity constitutes a connecting tool between the world of international law and an outside universe immediately raises some questions. Why make the foundational doctrines of international law (and the legal reasoning in connection with each of them) dependent on factual determination? Why expressly create a space in legal argumentation for factual determinations? Why not restrict legal reasoning to a purely normative or semantic exercise? Why do certain professionals of international law feel the need to connect international law's world of ideas with an outside (albeit self-created) universe?

It is argued here that part of the answer lies with the profession of international legal academics. More specifically, it is submitted here that the idea of effectivity alleviates a terrible fear for professionals who are not confronted with practice. This is the fear of being sequestered in their own world of ideas. Said even more explicitly, effectivity allows international academics to elude a self-perception that their profession boils down to theology and reassures them that they are not theologians. The idea of effectivity can be considered 
a powerful drug against epistemological claustrophobia for certain categories of professionals, and especially for legal academics and law professors. It helps turn international law into a body of knowledge about practice in the outside universe, and, simultaneously, it helps turn the experts of international law ideas into the experts of the outside universe of states, effective governments, customs, territory, wrongfulness, etc. As a result, once cured of their claustrophobic anxieties, legal academics, thanks to the idea of effectivity, are in a position to self-appoint themselves as astronauts in the outside universe.

\section{The Deceitful Idea of Effectivity}

It is important to conclude by emphasizing that this image of international law as the social science pertaining to occurrences in the self-created outside universe can be deceitful, at least when confronted with an external perspective. Indeed, because the idea of effectivity bridges the world of international law with an outside universe, it makes practitioners look as if they are in control of the universe that is imported into the world of international law. From an external perspective, practitioners are in the driver's seat in the outside universe and hence in international law as well. Those who decide in the outside universe are policy-makers, legal advisers, counsels, and judges, with legal academics only occupying a back seat. From such an external perspective, legal academics have, at best, spiritual authority.

This external imagery brought about by the idea of effectivity reveals the deceitfulness inherent therein. As was explained earlier, the idea of effectivity makes certain categories of professionals feel they are not theologians while making them look as if they have nothing more than spiritual authority. However, as the above remarks also point out, the idea of effectivity endows some of these professionals, particularly legal academics and law professors, with architectural responsibilities in the construction of the outside universe.

The foregoing should suffice to make clear that, for certain professionals of international law, there could not be a more comfortable position. These professionals define the vocabularies and ideas that are projected into the universe whilst being portrayed, from an external perspective, as wielding only spiritual authority over what goes on therein. Their position is one of immense authority, all of it veiled and concealed by the idea of effectivity. It does not seem controversial to hold that the greatest power lies in definition and description. By virtue of the smokescreen provided by the idea of effectivity, certain professionals of international law, especially legal academics, exert definitional power in secrecy and without much formal accountability but for the market-related or reputational.

Against that backdrop, there seems to be no doubt that the idea of effectivity will continue to prosper and inform scholarly debates and representations of the world for the next decades. Indeed, as is argued here, effectivity alleviates the fear of certain categories of professionals, particularly legal academics and law professors, of being relegated to the periphery. It provides them with a powerful drug against epistemological claustrophobia. Most importantly, it empowers these professionals with definitional power while allowing them to be perceived as sitting in the back seat. If these professionals relish power (as I secretly believe they do), they would be foolish to forsake the idea of effectivity. 